OPEN ACCESS

Edited by:

Han Xiao,

Peking University Third Hospital,

China

Reviewed by:

Xiaoxiang Yan,

Shanghai Jiao Tong University, China

Wei Liu,

The University of Manchester,

United Kingdom

Junjie Xiao,

Shanghai University, China

*Correspondence:

Chen Chen

chenchen@tjh.tjmu.edu.cn

Dao Wen Wang

dwwang@tjh.tjmu.edu.cn

Specialty section:

This article was submitted to

Clinical and Translational Physiology,

a section of the journal

Frontiers in Physiology

Received: 14 April 2021

Accepted: 25 May 2021

Published: 01 July 2021

Citation:

$\mathrm{LiH}$, Chen $\mathrm{C}$ and Wang DW

(2021) Inflammatory Cytokines,

Immune Cells, and Organ Interactions

in Heart Failure.

Front. Physiol. 12:695047.

doi: 10.3389/fphys.2021.695047

\section{Inflammatory Cytokines, Immune Cells, and Organ Interactions in Heart Failure}

\author{
Huihui Li $^{1,2}$, Chen Chen ${ }^{1,2 *}$ and Dao Wen Wang ${ }^{1,2 *}$ \\ 1 Division of Cardiology, Department of Internal Medicine, Tongji Hospital, Tongji Medical College, Huazhong University \\ of Science and Technology, Wuhan, China, ${ }^{2}$ Hubei Key Laboratory of Genetics and Molecular Mechanisms of Cardiological \\ Disorders, Tongji Hospital, Tongji Medical College, Huazhong University of Science and Technology, Wuhan, China
}

Despite mounting evidence demonstrating the significance of inflammation in the pathophysiological mechanisms of heart failure (HF), most large clinical trials that target the inflammatory responses in HF yielded neutral or even worsening outcomes. Further in-depth understanding about the roles of inflammation in the pathogenesis of HF is eagerly needed. This review summarizes cytokines, cardiac infiltrating immune cells, and extracardiac organs that orchestrate the complex inflammatory responses in HF and highlights emerging therapeutic targets.

Keywords: inflammation, heart failure, cytokine, immune cells, organs

\section{INTRODUCTION}

Heart failure (HF) is a clinical syndrome characterized by symptoms and signs induced by the structural and/or functional compromise of the heart, presents as dyspnea, fatigue, and fluid retention, and so on (Ponikowski et al., 2016; Yancy et al., 2017). HF is the principal cause of mortality and disability worldwide. In developed countries, the prevalence of HF is $1.5-2.2 \%$ (Mosterd and Hoes, 2007). The 1-year all-cause mortality rate of HF patients is 17 and $19.2 \%$ in Europe and Asia, respectively (Maggioni et al., 2013; Tromp et al., 2018a). HF could be divided into HF with reduced ejection fraction (HFrEF), HF with midrange ejection fraction, and HF with preserved ejection fraction (HFpEF) (Ponikowski et al., 2016). It is a syndrome caused by the complicated interaction of myocardial damage, neurohormonal activation, inflammatory response, and renal dysfunction (Mann, 2002; Zimmet and Hare, 2006; Braunwald, 2008). Although the etiology and pathogenesis of HF are still perplexing, the persistent inflammation of myocardium is believed to participate in the pathogenesis across the spectrum of HF subtypes in different ways (Dick and Epelman, 2016). Two recent biomarker profiles analyses, Counseling in Heart Failure (COACH) and Biology Study to Tailored Treatment in Chronic Heart Failure (BIOSTATCHF) trials, demonstrated a prominent correlation between inflammation and HFpEF, whereas HFrEF was more related to stretch-mediated interactions (Tromp et al., 2017, 2018b). This might partially be explained by the non-cardiac comorbidities of HFpEF patients such as diabetes mellitus, hypertension, obesity, anemia, chronic obstructive pulmonary disease, and chronic kidney disease. All of them are prone to systemic inflammatory state (Paulus and Tschope, 2013). However, most clinical trials using anti-inflammatory agents have provided disappointing results, reflecting the inadequate understanding about the sophisticated inflammatory network within the heterogenous performance of HF. Thus, a better illustration about how specific inflammatory cytokines, 
immune cells, and extracardiac organs collaborate and influence cardiac function may provide experimental basis for disease intervention and drug discovery.

\section{INFLAMMATORY CYTOKINES AND THEIR ROLES IN HF}

Since 1990, levels of several inflammatory mediators, including tumor necrosis factor $\alpha$ (TNF- $\alpha$ ), interleukin 6 (IL-6), IL$1 \beta$, IL-18, and immunological antigens, were validated to be increased in the plasma of HF patients (Torre-Amione et al., 1996; Anker and von Haehling, 2004; Braunwald, 2008). These suggested the "cytokine hypothesis" that inflammation contributed to the pathogenesis of HF (Seta et al., 1996; Mann, 2015). The elevated circulating cytokines might be produced by cardiac structural cells [cardiomyocytes (Kapadia et al., 1995), endothelial cells (Liu Y. et al., 2014), and fibroblasts (Sandanger et al., 2013)], various cardiac infiltrating immune cells (Pinto et al., 2016), and extracardiac tissues (hypoperfused skeletal muscle, lymphoid organs, intestinal tissue, and adipose tissue) (Murphy et al., 2020). Increased circulating cytokines do not only correlate with the severity of HF, but also possess prognostic value (Rauchhaus et al., 2000; Braunwald, 2008). Up to now, various functions of cytokines in HF were revealed (Table $\mathbf{1}$ ).

\section{Tumor Necrosis Factor}

Tumor necrosis factor $\alpha$ is the first cytokine discovered to be elevated in the peripheral blood of HF patients. Increased serum TNF- $\alpha$ level suggested impaired cardiac function and poor prognosis (Torre-Amione et al., 1996; Rauchhaus et al., 2000). TNF- $\alpha$ exerts its function through binding to the receptors. It is toxic with TNF receptor 1 (TNFR1) while protective with TNFR2 (Monden et al., 2007). Constantly increased TNF could attenuate $\beta 1$-adrenergic responsiveness, induce cell apoptosis, and destroy the balance between matrix metalloproteinases (MMPs) and tissue inhibitor of metalloproteinase, resulting in ventricular hypertrophy, dilatation, and diminished ejection fraction (Kubota et al., 1997; Tang et al., 2004; Zhang et al., 2011). Mice with TNF- $\alpha$ overexpression spontaneously progressed into end-stage dilated cardiomyopathy (DCM) (Tang et al., 2004). However, clinical trials that target TNF- $\alpha$ with infliximab [Anti-TNF Therapy Against Congestive Heart Failure Trial (ATTACH)] or etanercept [Randomized Etanercept Worldwide Evaluation Trial (RENEWAL)] yielded disappointing results and were terminated prematurely due to poor survival improvement and enhanced risk of hospitalization (Chung et al., 2003; Mann et al., 2004). Thus, further studies are needed to better understand the effects of TNF- $\alpha$ in HF.

Factor associated suicide (Fas), also named as APO-1, is a member of TNF receptor family, which is expressed in various tissues and cells including cardiomyocytes. Circulating level of Fas was elevated in HF patients and was associated with the severity of cardiac dysfunction (Okuyama et al., 1997). Blockade of the interaction between Fas and its ligands could improve survival rate and reduce ventricular remodeling in mice with myocardial infarction (MI). Thus, it might be a potential therapeutic target against chronic HF after MI (Li et al., 2004).

\section{IL-1 Family}

It was reported that IL-1 had a close association with HF. In patients with sepsis, IL-1 was considered to be a "soluble myocardial depressant factor" (Van Tassell et al., 2013b). Chronic hypoxia could induce IL-1 production in the cardiomyocytes (Kacimi et al., 1997). Circulating levels of IL-1 $\beta$ and IL-1 receptor antagonist (IL-1Ra) were increased in congestive HF patients (Testa et al., 1996). IL-1 could induce reversible negative inotropic effects on cardiomyocytes both in vitro (Liu and Schreur, 1995) and in vivo (Van Tassell et al., 2013a) through impairing $\beta$-adrenergic responsiveness and calcium handling (Buckley and Abbate, 2018). Meanwhile, blockade of IL-1 could restore calcium homeostasis, reduce inflammatory infiltration, and improve cardiac dysfunction (Van Tassell et al., 2012; Francis et al., 2014; Sager et al., 2015). Previous case reports indicated that in myocarditis-associated end-stage HF patients, blocking IL-1 improved cardiac contractility within 24 h (Cavalli et al., 2016, 2017). The prespecified subanalysis of the Canakinumab Antiinflammatory Thrombosis Outcome Study (CANTOS) showed that for patients with prior MI and elevated high-sensitivity C-reactive protein (hs-CRP), canakinumab effectively reduced HF-related hospitalization and all-cause mortality at a dosedependent manner (Everett et al., 2019). Thus, IL-1-targeted therapy may be beneficial to HF patients. Moreover, stratified analysis using multiple indexes revealed that HF patients with higher CRP could benefit more from anti-inflammatory therapy.

Suppression of tumorigenicity 2 (ST2), a decoy receptor of IL-33, is another member of IL-1 cytokine superfamily, which could be secreted by cardiomyocytes under mechanical strain (Weinberg et al., 2003). The increase in soluble ST2 (sST2) was independently and positively associated with poor outcomes in HF patients and might be valuable to predict prognosis (Anand et al., 2014).

\section{Interleukin 6}

Interleukin 6 acts as a downstream of IL-1, which attracted particular attention as a central factor in the pathophysiological processes of several inflammatory conditions. Preclinical researches indicated that IL-6 had pleiotropic adverse effects on cardiovascular system. Increased circulating IL-6 was reported in congestive HF patients, which had a significantly positive correlation with worsening cardiac symptom and renal dysfunction (Deswal et al., 2001; Plenz et al., 2001; Hanberg et al., 2018). Stimulation of isolated cardiomyocytes with IL-6 and soluble IL-6R could induce hypertrophy (Hirota et al., 1995), whereas IL-6 inhibition reduced cardiac hypertrophy and fibrosis in angiotensin II-treated mice (Coles et al., 2007). Although many IL-6-targeted therapies were used in the treatment of rheumatologic diseases and immune checkpoint inhibitorinduced cytokine release syndrome (Kang et al., 2019), clinical trials especially aimed at the therapeutic effects of anti-IL-6 on HF have not been implemented. A recent observational study containing 2,329 patients in the BIOSTAT-CHF cohort demonstrated that increased plasma IL-6 concentration was 
TABLE 1 | Cytokines in heart failure.

\begin{tabular}{|c|c|}
\hline Cytokines & Functions \\
\hline $\mathrm{TNF}-\alpha^{*}$ 放 $\square$ & Induce inflammatory genes expression and apoptosis, release proinflammatory cytokines, promote adverse remodeling \\
\hline Fas * 计 & Trigger programmed cell death \\
\hline $\mathrm{IL}-1 *$ 古 $\square$ & Induce negative inotropic effect through impairing $\beta$-adrenergic responsiveness and disturbing calcium handling \\
\hline 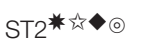 & Negatively modulate TLR signaling, inhibit nuclear factor $\kappa B$ activation \\
\hline IL-6*约 $\square$ & Pleiotropic proinflammatory responses \\
\hline $\mathrm{IL}-10^{*} \bullet$ & Inhibits proinflammatory cytokines secretion, block ROS release, modulate TNF- $\alpha$-mediated responses \\
\hline
\end{tabular}

* Participate in pathogenesis. ${ }^{\natural}$ Prognostic value. Identify high-risk patients. $\square$ Potential therapeutic target. ${ }^{\circ}$ Diagnostic value.

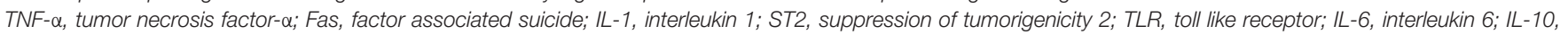
interleukin 10; ROS, reactive oxygen species.

positively correlated with atrial fibrillation, disturbed iron metabolism, poorer exercise tolerance, higher N-terminal pro-brain natriuretic peptide (NT-proBNP) concentrations, and lower estimated glomerular filtration rate (MarkousisMavrogenis et al., 2019). Besides, circulating IL-6 concentration was independently predictive of all-cause and cause-specific mortality (Markousis-Mavrogenis et al., 2019).

\section{Interleukin 10}

Interleukin-10 is generally considered as an anti-inflammatory cytokine with pleiotropic function. It inhibits the secretion of various proinflammatory cytokines, especially TNF- $\alpha$ (Kaur et al., 2006; Ouyang et al., 2011). The protein and mRNA levels of membrane-bound IL-10 were dramatically reduced in the heart of mice with acute MI (AMI) (Kaur et al., 2006). Moreover, it was negatively correlated with the cardiac function and progression to congestive HF (Kaur et al., 2006). In the heart samples of DCM patients, IL-10 expression was decreased and negatively associated with the disease severity (Ukimura et al., 2003). Although there has yet to be a clinical trial that specifically regulates IL-10 in HF patients, treatment with growth hormone or intravenous immunoglobulin has been shown to be associated with a marked increase in plasma IL-10 level and consequently improved cardiac contractile performance in $\mathrm{HF}$ patients (Gullestad et al., 2001; Adamopoulos, 2003).

\section{IMMUNE CELLS AND THEIR ROLES IN HF}

The heart harbors all of the major immune cell types in the steady state, including monocytes, macrophages, $\mathrm{T}$ cells, neutrophils, $\mathrm{B}$ cells, dendritic cells (DCs), natural killer (NK) cells, and mast cells (Pinto et al., 2016). The number of immune cells in the heart from a healthy adult mouse is more than 10-fold than in skeletal muscle (Ramos et al., 2017). Immune cells participate in the pathogenesis of various inflammatory and non-inflammatory cardiovascular diseases (Adamo et al., 2020). Previous researches revealed a positive correlation between peripheral blood immune cell level and left ventricular dysfunction both in animal model and HF patients (Yndestad, 2003; Fukunaga et al., 2007a; Pistulli et al., 2016). Apart from circulating inflammatory cells, transcriptional sequencing of human heart samples showed diverse expression profiles of innate immune responses related genes between failing and non-failing hearts (Mann et al., 2010). Endomyocardial biopsy in HF and DCM patients revealed a $30 \%$ detection rate of myocardial inflammatory infiltration (Kuhl and Schultheiss, 2012). A research using dual-target positron emission tomography $(\mathrm{PET}) /$ magnetic resonance imaging to monitor the size of immune cell population indicated a large number of inflammatory monocytes, macrophages, and neutrophils existed in the cardiac tissue after MI (Keliher et al., 2017). Another research demonstrated that inflammatory cells especially macrophages and $\mathrm{T}$ cells infiltrated in the heart of DCM patients without any discernible viral infection history (Noutsias et al., 2002). Studies from different animal models have revealed various potential therapeutic targets focusing on these immune cells in HF (Table 2).

\section{Macrophages}

Macrophages, one of the most abundant immune cell types in the heart, are commonly divided into M1 and M2 types due to cell surface markers and their functions in inflammatory responses. Recently, this classification criterion was considered imperfect because of the plasticity and highly variable cell surface marker expression of macrophages. Evidence from singlecell sequencing and genetic fate mapping indicated that the expression levels of CCR2 and MHC-II were sufficient to classify macrophage populations in adult mouse heart (Epelman et al., 2014; Hulsmans et al., 2017; Lavine et al., 2018). At healthy status, heart macrophages were dominated by CCR2macrophages, which could further divide into two categories by MHCII expression (CCR2 ${ }^{-} \mathrm{MHCII}^{\text {high }}$ macrophage and $\mathrm{CCR}^{+}{ }^{+} \mathrm{MHCII}^{\text {low }}$ macrophage). CCR2 ${ }^{-}$macrophages originate from embryonic precursor, mainly function in coronary system development, angiogenesis, and immune quiescence (Epelman et al., 2014; Lavine et al., 2014). In addition, CCR2- MHCII ${ }^{\text {high }}$ macrophages have a special role in presenting antigens to $\mathrm{T}$ cells (Epelman et al., 2014; Leid et al., 2016). A small, but more proinflammatory $\mathrm{CCR}^{+} \mathrm{MHCII}^{\text {high }}$ macrophage populations also exist in the healthy heart, which were maintained and renewed by circulating Ly6 $\mathrm{C}^{\text {high }} \mathrm{CCR} 2^{+}$monocytes influx (Leid et al., 2016). In the heart tissue of transverse aortic constrictioninduced HF mice, myocardial expression of CCR2 ligand such as CCL2, CCL7, and CCL12 was enhanced, accompanied with significantly increased proinflammatory monocyte-derived 
TABLE 2 | Main immune cells in heart failure.

\begin{tabular}{|c|c|c|}
\hline Immune cells & Functions & $\begin{array}{l}\text { Potential therapeutic targets from } \\
\text { animal studies }\end{array}$ \\
\hline Macrophages & $\begin{array}{l}\text { Elevated } \mathrm{CCR}^{+}{ }^{+} \mathrm{MHCI}{ }^{\text {high }} \mathrm{Ly}_{6 \mathrm{c}^{+}} \text {macrophages in myocardium could secrete } \\
\text { inflammatory cytokines and contribute to ventricular dysfunction }\end{array}$ & CCR2-CCL2 signaling axis \\
\hline Mast cells & Attenuate left ventricular remodeling and promote cardiac dysfunction & Mast cell depletion \\
\hline Neutrophils & Destructive at acute stage and protective at chronic stage & Annexin A1 \\
\hline Natural killer cells & Release cytokines and modulate immune system & \\
\hline Dendritic cells & Protective at acute stage and destructive at chronic stage & \\
\hline \multirow[t]{3}{*}{ CD4+ T cells } & $\mathrm{T}_{H} 1$ cells are mainly proinflammatory & \\
\hline & $\mathrm{T}_{H} 2$ cells are mainly profibrosis & \\
\hline & $\begin{array}{l}\mathrm{T}_{H} 17 \text { cells contribute to cardiac hypertrophy and promote adverse cardiac } \\
\text { remodeling }\end{array}$ & \\
\hline B cells & Induce direct myocardial injury, produce inflammatory cytokines, and antibodies & B-cell depletion \\
\hline
\end{tabular}

$\mathrm{CCR}^{+}$macrophages (Xia et al., 2009; Liao et al., 2018; Patel et al., 2018). The increased CCR2 ${ }^{+}$macrophages could produce inflammatory cytokines and chemokines, resulting in cardiac T-cell expansion, contributing to cardiomyocyte damage, cardiac remodeling, and pathological hypertrophy (Patel et al., 2018). Clinically, the abundance of CCR2 ${ }^{+}$macrophage was positively associated with adverse left ventricular remodeling and persistent left ventricular dysfunction in HF patients (Bajpai et al., 2018; Dick et al., 2019). Thus far, no CCR2 modulating therapy has been approved for clinical indications. But previous animal experiments targeting the CCR2-CCL2 signaling axis through various approaches such as CCR2 antagonists and monoclonal antibody (Hilgendorf et al., 2014; Liao et al., 2018; Patel et al., 2018), CCR2-targeting PEG-DSPE micelles (Wang et al., 2018), RNA silencing technique targeted on endothelial cell adhesion molecules (Sager et al., 2016), silencing of macrophage polarization factor IRF5 (interferon regulatory factor 5) (Courties et al., 2014), immune-modifying microparticles infusion (Getts et al., 2014), and CCR2-targeted lipid nanoparticle-encapsulated small interfering RNA (Gordon, 2012) had obtained therapeutic benefits both in ischemic and non-ischemic HF by attenuating the proinflammatory monocyte infiltration in the myocardium. These results highlight the potential of CCR2-CCL2 signaling axis-targeted therapy. Apart from that, a recent single-cell sequencing study indicated that in pressure overload HF mice, $\mathrm{CCR} 2^{+} \mathrm{M} 1$ like proinflammatory macrophages, expressed a high level of oncostatin M (OSM) (Martini et al., 2019), which exerted a major role of cardiomyocyte dedifferentiation and remodeling during AMI and in DCM (Kubin et al., 2011). OSM was identified to mediate the TNF- $\alpha$-resistant effect in inflammatory bowel disease patients. This might partially explain the refractivity of HF patients to anti-TNF- $\alpha$ therapy (West et al., 2017).

\section{Mast Cells}

Mast cells were originally defined as effectors of allergy and anaphylactic reactions. However, recent researches have validated that cardiac mast cells also participated in other physiological processes, including vascular homeostasis and angiogenesis (da Silva et al., 2014). Mast cells harbor granules that store histamine, proteases, various cytokines, chemokines, and growth factors in the cytoplasm and exert their function through degranulation (Mukai et al., 2018). Researches indicated that the number of mast cells was significantly increased in the heart of end-stage cardiomyopathy patients, which promoted cardiac adverse remodeling through activating MMPs and myocardial fibrillar collagen degradation (Akgul et al., 2004; Levick et al., 2011). Either depletion of mast cells or inhibition of their degranulation could attenuate left ventricular remodeling and cardiac dysfunction, as well as improve survival rate in animal models (Hara et al., 2002; Brower and Janicki, 2005; Liu Y. H. et al., 2014). Thus, cardiac mast cell population may be a potential target for cardioprotection.

\section{Neutrophils}

Neutrophils are the most abundant type of circulating leucocytes in human, and recognized as the first responder to acute inflammatory response. Cumulative evidence indicated that neutrophils played a pivotal role in chronic inflammation as well (Bonaventura et al., 2019). Neutrophils participate in various cardiovascular diseases via releasing degranulation products, recruiting and activating macrophages and pDCs, delivering microvesicle and cytokine, and so on (Bonaventura et al., 2019). Some researches indicated that the blood count of neutrophil was positively correlated with the severity of coronary damage in coronary artery disease patients (Sharma et al., 2017). Neutrophil/lymphocyte ratio could predict acute HF patients with a higher risk of vascular events (Uthamalingam et al., 2011). In patients with AMI that developed congestive HF, $92.5 \%$ had relative neutrophilia (neutrophil percentage $>65 \%$ ), whereas in patients with AMI that did not develop into congestive HF, the incidence of neutrophilia was 45\% (Kyne et al., 2000). Previously, it was believed that neutrophils exerted a proinflammatory effect and augmented heart damage in MI. The increased counts or volume of circulating neutrophils after MI was positively correlated with infarction size and negatively correlated with left ventricular function and clinical outcomes (Chia et al., 2009; van Hout et al., 2015). However, recently, researchers found that in infarct healing process, neutrophils could promote macrophages polarization toward a proreparative 
and proangiogenesis phenotype through releasing gelatinaseassociated lipocalin (NGAL) and annexin A1 (Horckmans et al., 2017; Ferraro et al., 2019). Accordingly, depletion of neutrophils in mice led to worsening cardiac function, increased cardiac fibrosis, and enhanced expression of HF biomarkers after MI (Horckmans et al., 2017). Besides, annexin A1 knockout mice subjected to MI were stagnated in macrophages repolarization and exhibited impeded healing after MI. Annexin A1 treatment significantly improved cardiac function both in mice and pig (Ferraro et al., 2019). In addition, another research indicated that OSM produced by neutrophils and macrophages after MI could induce the release of regenerating islet-derived protein $3 \beta$ (Reg3 $\beta$ ), an essential regulator of macrophage trafficking, from dedifferentiating cardiomyocytes, which further promoted the accumulation of proreparative macrophages in the damaged heart (Lorchner et al., 2015). Thus, special attention should be given on the timing of neutrophil targeted therapy in respect of the clinical course pattern of neutrophil function in HF.

\section{NK Cells}

Natural killer cells were primarily recognized as the major effector lymphocytes of innate immune responses endowed with constitutive cytolytic functions. They play a significant role in repairing damaged tissue and maintaining tissue homeostasis (Tosello-Trampont et al., 2017). In addition, NK cells possess complex biological functions in modulating the immune system through receptor-ligand interactions or release various cytokines and chemokines, such as enhancing the antigen-presenting ability of DCs and dampening macrophage/T-cell responses (Vivier et al., 2011; Ong et al., 2017). Circulating NK cells were dramatically reduced in number with diminished cytolytic function in HF patients, as well as coronary heart disease patients and ischemic heart disease patients (Anderson et al., 1982; Vredevoe et al., 2004; Jonasson et al., 2005; Hou et al., 2012; Backteman et al., 2014). Consistent NK cell deficiency was correlated with low-grade chronic cardiac inflammation, while cardiac inflammation was diminished in patients with restored circulating NK cells (Vredevoe et al., 2004; Backteman et al., 2014). Whether this observation is causative or merely a concomitant phenomenon remains to be clarified. The cytolytic impairment of NK cells was associated with increased IL6 level, but the underlying molecular mechanism was not revealed (Vredevoe et al., 2004). By preventing inflammatory cell accumulation and limiting collagen production from cardiac fibroblasts, NK cells could suppress the development of cardiac fibrosis (Ong et al., 2017). Further investigation is urgently needed to clarify the role of NK cells in HF.

\section{Dendritic Cells}

As the sentinels of immune system, DCs serve as a bridge linking adaptive and innate immune responses (Mildner and Jung, 2014). Heart-specific self-peptide loaded DCs were capable to induce $\mathrm{CD}^{+}{ }^{+} \mathrm{T}$-cell-mediated myocarditis and autoimmune HF in mice (Eriksson et al., 2003). In AMI, the migration and accumulation of DCs to the infarction site were increased and DC depletion resulted in worsening post-MI remodeling (Anzai et al., 2012). The number of proinflammatory monocytes and macrophages increased in the myocardium of DCdepleted mice, indicating that DCs might act as an immuneprotective regulator during the postinfarction healing process via regulating monocyte/macrophage homeostasis (Anzai et al., 2012). However, DC infiltration was decreased in the cardiac tissue of symptomatic DCM patients, which indicated a damaged ejection fraction (Pistulli et al., 2013). Thus, the function of DCs may be different in acute and chronic HF.

\section{T Cells}

$\mathrm{T}$ cell is the major element of the adaptive immune response. Initial evidence implicated that $\mathrm{T}$ cells that participated in the pathogenesis of HF came from the elevated $\mathrm{T}$ cell-generated cytokines, IL-2 and IL-10, in the plasma of HF patients (Marriott et al., 1996). Then, circulating T cells from congestive HF patients were validated to have enhanced expression of T-cell activation markers (CD25 and CD69), chemokines, and proinflammatory cytokines [TNF- $\alpha$, interferon $\gamma$ (IFN- $\gamma$ ), and IL-18] (Yndestad, 2003). Circulating inflammatory cytokines produced by $\mathrm{T}$ cells had a positive correlation with left ventricular dysfunction in chronic ischemic HF and idiopathic DCM patients (Fukunaga et al., 2007b). The proportion of regulatory $T$ (Treg) cells in the plasma of HFrEF patients was decreased with less suppressive activity, whereas the proportion of proinflammatory T-helper 17 ( $\left.\mathrm{T}_{H} 17\right)$ cells was increased (Li N. et al., 2010; Tang H. et al., 2010; Tang T. T. et al., 2010; Okamoto et al., 2014). The number of Treg cells was negatively associated with the levels of NT-proBNP, CRP, and IL- 6 and possessed a prognostic value in predicting cardiac function (Tang et al., 2011; Okamoto et al., 2014).

$\mathrm{CD}^{+}$and $\mathrm{CD}^{+} \mathrm{T}$ cells, as well as $\mathrm{CD} 4^{+}$subsets $\left(\mathrm{T}_{H} 1\right.$, $\mathrm{T}_{H} 2, \mathrm{~T}_{H} 17$, and Treg cells), are also infiltrated in the failing heart (Nevers et al., 2015; Martini et al., 2019). Although bulk blockade of $\mathrm{CD}^{+}{ }^{+} \mathrm{T}$ cells in mice prevented cardiac remodeling and exhibited preserved contractile function (Laroumanie et al., 2014), the roles of $\mathrm{CD}^{+}{ }^{+} \mathrm{T}$-cell subtypes are quite different. $\mathrm{T}_{H} 1$ cells are mainly proinflammatory and could activate proinflammatory macrophages, whereas $\mathrm{T}_{H} 2$ responses are mainly profibrotic. T-bet, a $\mathrm{T}_{H} 1$ cell-specific transcription factor, was detected to be elevated in hypertrophic myocardium of patients. T-bet deficiency improved pressure overload-induced cardiac remodeling in rats, indicating the potential therapeutic value of T-bet for HF treatment (Ma et al., 2018). $\mathrm{T}_{H} 17$ cells have been reported to contribute to cardiac hypertrophy and promote adverse cardiac remodeling (Frieler and Mortensen, 2015). IL-17 is an effector molecule of $\mathrm{T}_{H} 17$ cells; blockade of IL-17 cells was beneficial in DCM and MI disease models (Baldeviano et al., 2010; Liao et al., 2012). Treg cells are known to negatively regulate the immune response and suppress the effector functions of T-helper cells (Meng et al., 2016). But a recent research indicated that in non-reperfused MIinduced $\mathrm{HF}$ mice, myocardial infiltrating $\mathrm{CD} 4^{+} \mathrm{Foxp}^{+}$Treg cells exhibited proinflammatory $\mathrm{T}_{H}$ 1-type features with the expression of IFN- $\gamma$, TNF- $\alpha$, and TNFR1 and had decreased immunomodulatory capacity with potentiated antiangiogenic and profibrotic properties. Periodic Treg-cell depletion reversed left ventricular remodeling, reduced cardiac fibrosis, and improved neovascularization. Treg cell reconstitution after their 
depletion could restore immunomodulatory capacity (Bansal et al., 2019). Besides, in mice with existing left ventricular failure, administration of IL-2 (also named as T-cell growth factor) significantly increased Tregs in the lung, consecutively reduced pulmonary macrophages and $\mathrm{CD}^{+} \mathrm{T}$ cell infiltration, and attenuated right ventricular hypertrophy (Wang et al., 2016). Thus, Treg cells may be a potential high-yield target for the treatment of ischemic cardiomyopathy and HF. Furthermore, single-cell sequencing of the heart tissues from pressure overload HF mice indicated that Treg-cell population expressed a high level of programmed cell death protein 1 (PD-1), which might partially explain the cardiac toxicity during anti-PD-1 cancer immunotherapy (Martini et al., 2019).

\section{B Cells}

The density of B-cell population increased in the myocardium of both acute cardiac MI and pressure-overload HF mice (Yan et al., 2013; Martini et al., 2019). B cells could produce proinflammatory cytokines including TNF- $\alpha$, lymphotoxin, IL-1, and IL-6 after acquiring cytokine secretion capability. These cytokines were reported to attenuate left ventricular function and promote cardiac remodeling (Vazquez et al., 2015). Activated B cells could also directly induce cardiomyocyte damage through complement-mediated cytotoxicity (CorderoReyes et al., 2013). After AMI, B cells could produce CCL7 to chemoattract Ly6C high monocyte to local heart, resulting in tissue damage and myocardial function deterioration (Zouggari et al., 2013). Besides, B cells produced various antibodies, which might precede disease manifestation. Several antibodies against proteins in the heart, including $\beta 1$ adrenergic receptor, M2 receptor, myosin heavy-chain $\alpha$ and $\beta$, troponin I, Na-K-ATPase, and $\mathrm{Kv}$ channel, were reported to be elevated in DCM patients (Kaya et al., 2012). Antibodies deposited in the myocardium could exert direct injury and contribute to cardiac electrical instability (Cordero-Reyes et al., 2013). Serum levels of anti-heart autoantibodies were proven to be negatively associated with inotropic effects and could independently predict 5-year prognosis (Caforio et al., 2007; Kaya et al., 2012). In angiotensin II-induced HF mice model, B-cell depletion by anti-CD22 antibody resulted in reduced cardiomyocyte apoptosis, proinflammatory cytokines levels, and immunoglobulin G deposition in the myocardium; alleviated cardiac hypertrophy; and preserved left ventricular function (Cordero-Reyes et al., 2016). Therapies that depleted B cells with rituximab (CD20specific antibody) diminished myocardial injury and improved cardiac function in patients with inflammatory DCM (Tschope et al., 2019) or AMI (phase I/II study) (Zouggari et al., 2013). Therefore, B-cell-targeted therapy is an appealing option in HF treatment.

\section{EXTRACARDIAC ORGANS}

As a systemic disease of HF, inflammatory cells and cytokines would not only affect cardiac function but also contribute to multiorgan damage through various mechanisms (Figure 1).

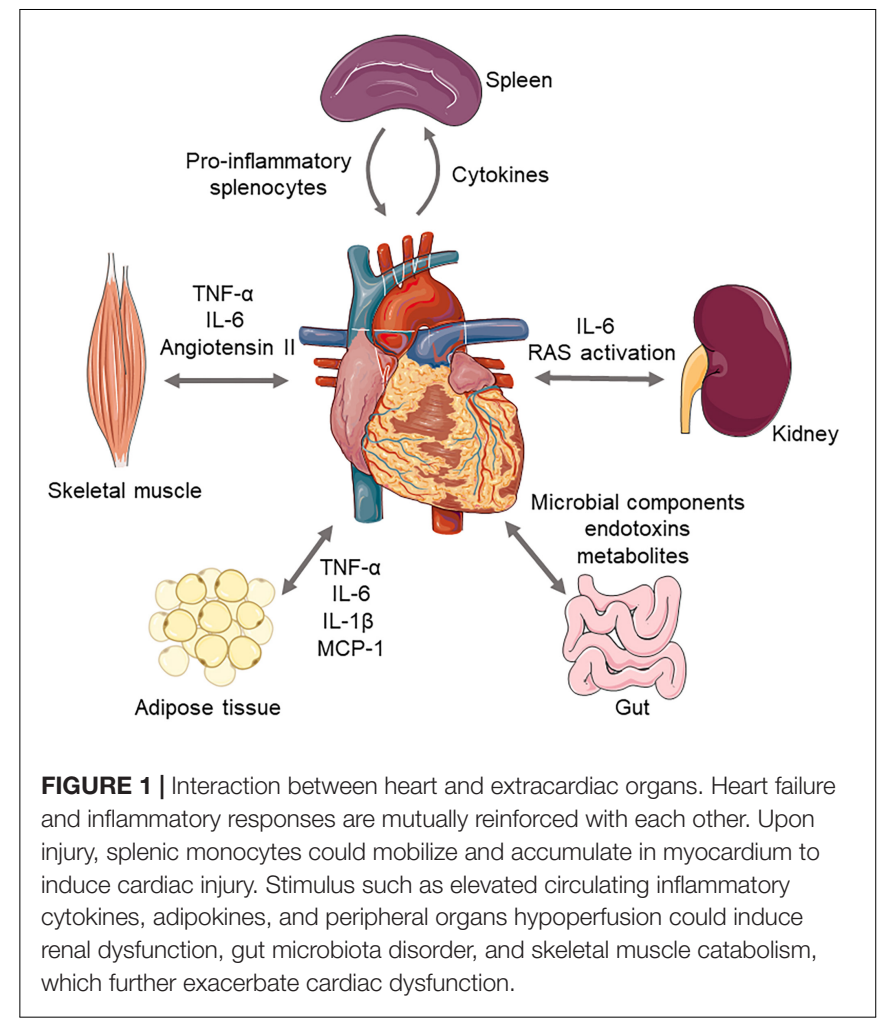

Conversely, remote organ-related inflammatory responses would further deteriorate cardiac function.

\section{Cardiosplenic Axis}

Clinical study that using ${ }^{18} \mathrm{~F}$-fluorodeoxyglucose PET to measure the glucose metabolic rate of patients after MI revealed increased metabolic activity (reflects enhanced inflammatory cell activity) in the spleen (Wollenweber et al., 2014). Thus, remote organs might also participate in the inflammatory process of HF. Spleen harbors a large reservoir of undifferentiated monocytes. Upon injury, splenic monocytes could increase motility and accumulate in damaged tissues to regulate inflammation and promote healing process (Swirski et al., 2009). After AMI, a unique spatiotemporal pattern of a marked depletion of splenic monocytes that coincided with the accumulation of myocardial monocytes supported the hypothesis of cardiosplenic axis (van der Laan et al., 2014). HF mice underwent splenectomy showed attenuated monocyte-derived tissue macrophages and DC infiltration and reversed cardiac remodeling, whereas adoptive transfer of splenic monocytes from HF mice could induce left ventricular dysfunction and fibrosis in recipient mice (Ismahil et al., 2014). Therefore, cardiosplenic axis might play an important role in the pathogenesis of HF.

\section{Cardiorenal Interaction}

End-stage renal disease and severe cardiovascular dysfunction are closely related to each other, which is termed as cardiorenal syndrome (CRS) (Bock and Gottlieb, 2010). Inflammatory responses, especially IL-6-related pathway, are thought to be 
a crucial driver of CRS in HF patients. A research containing $98 \mathrm{HF}$ patients found that increased plasma IL- 6 concentration was correlated with higher mortality risk, whereas elevated urine IL-6 level (quantify inflammation at the level of renal tissue) was independently associated with renal dysfunction (Hanberg et al., 2018). Previous studies demonstrated that IL-6 could impair pressure natriuresis and exacerbate renal function through activating renal epithelial sodium (ENaC) ( $\mathrm{Li} \mathrm{K}$. et al., 2010) and promoting the expression of fibrotic and endothelin1 gene (Zhang et al., 2012). Apart from the cytokine-induced renal damage, the activation of renal-angiotensin system plays a vital role in CRS. The elevated angiotensin II stimulated cardiomyocytes to release proinflammatory cytokines, including TNF- $\alpha$ and IL-1, which are involved in the complex mechanisms of HF (Kalra et al., 2002; Ruiz-Ortega et al., 2002).

\section{Gut Microbiota}

Cumulative evidence has implied the significance of intestinal microbiota in various diseases including HF. The reduced cardiac output leads to intestinal ischemia, edema, and increased gut permeability, making it possible for the entry of bacteria, endotoxins, and metabolites into the bloodstream. Edematous HF patients had higher blood concentrations of lipopolysaccharide (Sandek et al., 2012). Meanwhile, higher endotoxin levels in hepatic veins than left ventricle during acute HF suggested the translocation of microbial components or endotoxins from the bowel into the circulating blood (Peschel et al., 2003). Translocation of lipopolysaccharide activated the inflammatory pathways, promoted the expression of cytokines, and contributed to HF progression (Verbrugge et al., 2013; Liu et al., 2015). Thus, probiotics and antibiotics such as rifaximin could be used in HF patients to attenuate systemic inflammation and restore metabolic homeostasis through gut microbiota modulation.

\section{Cardioadipose Tissue Crosstalk}

The relationship between $\mathrm{HF}$ and obesity has long been recognized (Abel et al., 2008). Obesity is an independent risk factor for HF, especially in HFpEF. But some studies indicated that HF patients with higher body mass index and waist circumference had better prognosis than lean patients. This phenomenon has been defined as "obesity paradox" (Lavie et al., 2016; Carbone et al., 2017). Although the detailed mechanism behind this discrepancy is not clear, inflammation might be involved (Karason and Jamaly, 2020). It is widely accepted that obesity could promote systemic inflammation (Berg and Scherer, 2005; Ghigliotti et al., 2014). In obesity, visceral fat, as well as epicardial and pericardial fat, enhanced the expression of various proinflammatory cytokines, including TNF- $\alpha$, IL-6, IL-1 $\beta$, and monocyte chemoattractant protein 1 , whereas it reduced the expression of anti-inflammatory cytokines, such as IL-10 and adiponectin (Jahng et al., 2016). The chronic systemic inflammation in obesity further promoted the accumulation of epicardial fat and adversely damaged the biology of epicardial fat toward a proinflammatory phenotype (Hirata et al., 2011; Wernstedt Asterholm et al., 2014). The proinflammatory adipocytokines, gaseous messengers, and lipids secreted by epicardial adipose tissue could affect cardiomyocytes and extracellular matrix through a paracrine manner (Patel et al., 2017). Thus, epicardial fat could serve as a transducer that mediated the influence of systemic inflammation on adjacent myocardium (Packer, 2018). This might partially explain the cardiac sterile inflammation in obese people. On the other hand, in HF patients, damaged cardiomyocytes could release proinflammatory cytokines, such as IL- 6 and TNF- $\alpha$, which could trigger lipolysis of epicardial adipose tissue, leading to cardiac cachexia and worsening outcome (Oikonomou and Antoniades, 2019). Strategies that reduced the quantity of epicardial adipose tissue, such as high doses of statins (Abe et al., 2008; Alexopoulos et al., 2013; Cho et al., 2015; Yamada et al., 2017), metformin (Jonker et al., 2010; Cameron et al., 2016), mineralocorticoid receptor antagonists (Guo et al., 2008; Anand et al., 2017; Olivier et al., 2017), sodium-glucose cotransporter 2 inhibitors (Habibi et al., 2017; Lee et al., 2017), as well as low-calorie diets and physical exercise (Kim et al., 1985; Kelly et al., 2014), could reduce systemic inflammation, prevent, or treat HFpEF.

\section{Heart and Skeletal Muscle Crosstalk}

Heart failure patients are frequently accompanied with skeletal muscle wasting, which is generally not associated with body

TABLE 3 | Ongoing clinical trials targeting inflammation.

\begin{tabular}{|c|c|c|c|c|c|c|}
\hline Drug & Trial identifier & Disease & Primary endpoint & $\begin{array}{l}\text { Duration } \\
\text { of therapy }\end{array}$ & $\begin{array}{l}\text { Phase and } \\
\text { status }\end{array}$ & Sponsor \\
\hline Anakinra (interleukin 1 blockade) & NCT03797001 & $\begin{array}{l}\text { Heart failure, systolic, } \\
\text { inflammation }\end{array}$ & $\begin{array}{c}\text { Changes in peak } \mathrm{VO}_{2} \text { at } \\
\text { earlier endpoints }\end{array}$ & 24 Weeks & $\begin{array}{l}\text { Phase 2; } \\
\text { recruiting }\end{array}$ & $\begin{array}{c}\text { Virginia Commonwealth } \\
\text { University }\end{array}$ \\
\hline Proleukin (interleukin 2) & NCT03113773 & Ischemic heart disease & - & 5 Days & $\begin{array}{c}\text { Phase } 1 / 2 ; \\
\text { active, not } \\
\text { recruiting }\end{array}$ & $\begin{array}{c}\text { Cambridge University } \\
\text { Hospitals NHS Foundation } \\
\text { Trust }\end{array}$ \\
\hline Interleukin 2 (IL-2) & NCT04241601 & $\begin{array}{l}\text { Acute coronary } \\
\text { syndromes }\end{array}$ & $\begin{array}{l}\text { Change in vascular } \\
\text { inflammation }\end{array}$ & 5 Days & $\begin{array}{l}\text { Phase 2; } \\
\text { recruiting }\end{array}$ & $\begin{array}{c}\text { Cambridge University } \\
\text { Hospitals NHS Foundation } \\
\text { Trust }\end{array}$ \\
\hline Colchicine (anti-inflammatory) & NCT04857931 & $\begin{array}{l}\text { Heart failure, } \\
\text { inflammation }\end{array}$ & $\begin{array}{l}\text { Change in hs-CRP } \\
\text { (C-reactive protein) }\end{array}$ & - & $\begin{array}{l}\text { Phase } 3 \text {; not } \\
\text { yet recruiting }\end{array}$ & Montreal Heart Institute \\
\hline Colchicine (anti-inflammatory) & NCT04420624 & $\begin{array}{l}\text { Myocardial infarction, } \\
\text { acute }\end{array}$ & $\begin{array}{c}\text { Percentage of myocardial } \\
\text { denervation }\end{array}$ & 1 Month & $\begin{array}{l}\text { Phase 2/3; } \\
\text { recruiting }\end{array}$ & $\begin{array}{l}\text { University Hospital, } \\
\text { Montpellier }\end{array}$ \\
\hline
\end{tabular}


weight loss but mainly due to the imbalance of the muscle protein synthesis and degradation (von Haehling et al., 2013; Ebner et al., 2014). The elevated circulating cytokines such as TNF- $\alpha$ and IL- 6 in HF patients could induce muscle protein loss by activating nuclear factor $\kappa \mathrm{B}$ pathway (Li et al., 1998; Lavine and Sierra, 2017) and lead to skeletal muscle apoptosis through promoting sphingosine production (Dalla Libera et al., 2001). Besides, activated angiotensin II in HF patients was involved in the metabolism of skeletal muscle (Delafontaine and Akao, 2006; Sukhanov et al., 2011). In HF patients, damaged or dying myocytes could release various danger-associated molecular patterns and myokines, such as myostatin, IL-8, IL15 , and osteonectin, into plasma, which contribute to HF-related myopathy (Chan et al., 2012; Berezin et al., 2021).

\section{CONCLUSION}

Immune activation possesses a vital role in the progression of HF. However, anti-inflammatory clinical trials showed limited success. The diverse clinical etiologies and the intrinsic complexity of inflammatory responses may partially explain these unsatisfied results. Further insights and clinical trials about inflammation in specific etiologies and stages of $\mathrm{HF}$ are needed (Table 3). Furthermore, stratifying the HF patients into particular

\section{REFERENCES}

Abe, M., Matsuda, M., Kobayashi, H., Miyata, Y., Nakayama, Y., Komuro, R., et al. (2008). Effects of statins on adipose tissue inflammation: their inhibitory effect on MyD88-independent IRF3/IFN-beta pathway in macrophages. Arterioscler. Thromb. Vasc. Biol. 28, 871-877. doi: 10.1161/atvbaha.107.160663

Abel, E. D., Litwin, S. E., and Sweeney, G. (2008). Cardiac remodeling in obesity. Physiol. Rev. 88, 389-419. doi: 10.1152/physrev.00017.2007

Adamo, L., Rocha-Resende, C., Prabhu, S. D., and Mann, D. L. (2020). Reappraising the role of inflammation in heart failure. Nat. Rev. Cardiol. 17, 269-285. doi: 10.1038/s41569-019-0315-x

Adamopoulos, S. (2003). Effects of growth hormone on circulating cytokine network, and left ventricular contractile performance and geometry in patients with idiopathic dilated cardiomyopathy. Eur. Heart J. 24, 2186-2196. doi: 10.1016/s0195-668x(03)00480-9

Akgul, A., Skrabal, C. A., Thompson, L. O., Loebe, M., Lafuente, J. A., Noon, G. P., et al. (2004). Role of mast cells and their mediators in failing myocardium under mechanical ventricular support. J. Heart Lung Transplant. 23, 709-715. doi: 10.1016/j.healun.2003.06.006

Alexopoulos, N., Melek, B. H., Arepalli, C. D., Hartlage, G. R., Chen, Z., Kim, S., et al. (2013). Effect of intensive versus moderate lipid-lowering therapy on epicardial adipose tissue in hyperlipidemic post-menopausal women: a substudy of the BELLES trial (Beyond Endorsed Lipid Lowering with EBT Scanning). J. Am. Coll. Cardiol. 61, 1956-1961. doi: 10.1016/j.jacc.2012.12. 051

Anand, I. S., Claggett, B., Liu, J., Shah, A. M., Rector, T. S., Shah, S. J., et al. (2017). Interaction between spironolactone and natriuretic peptides in patients with heart failure and preserved ejection fraction: from the TOPCAT trial. JACC Heart Fail. 5, 241-252. doi: 10.1016/j.jchf.2016.11.015

Anand, I. S., Rector, T. S., Kuskowski, M., Snider, J., and Cohn, J. N. (2014). Prognostic value of soluble ST2 in the valsartan heart failure trial. Circ. Heart Fail. 7, 418-426. doi: 10.1161/circheartfailure.113.001036

Anderson, J. L., Carlquist, J. F., and Hammond, E. H. (1982). Deficient natural killer cell activity in patients with idiopathic dilated cardiomyopathy. Lancet 2, 1124-1127. doi: 10.1016/s0140-6736(82)92786-6 subpopulations according to their inflammatory conditions may maximize the effects of anti-inflammatory therapy.

\section{AUTHOR CONTRIBUTIONS}

HL and CC conceived and wrote the manuscript. DW supervised and wrote the manuscript. All authors contributed to the article and approved the submitted version.

\section{FUNDING}

This work was supported by grants from the National Natural Science Foundation of China (91839302, 81630010, and 81790624 to DW); the Natural Science Foundation of Hubei Province (2020CFA016 to CC); and the Tongji Hospital Clinical Research Flagship Program (2019CR207 to DW). No funding bodies had any role in study design, data collection and analysis, decision to publish, or preparation of the manuscript.

\section{ACKNOWLEDGMENTS}

We thank our colleagues from Division of Cardiology, Tongji Hospital for stimulating discussions during this investigation.

Anker, S. D., and von Haehling, S. (2004). Inflammatory mediators in chronic heart failure: an overview. Heart 90, 464-470. doi: 10.1136/hrt.2002.007005

Anzai, A., Anzai, T., Nagai, S., Maekawa, Y., Naito, K., Kaneko, H., et al. (2012). Regulatory role of dendritic cells in postinfarction healing and left ventricular remodeling. Circulation 125, 1234-1245. doi: 10.1161/circulationaha.111. 052126

Backteman, K., Ernerudh, J., and Jonasson, L. (2014). Natural killer (NK) cell deficit in coronary artery disease: no aberrations in phenotype but sustained reduction of NK cells is associated with low-grade inflammation. Clin. Exp. Immunol. 175, 104-112. doi: 10.1111/cei.12210

Bajpai, G., Schneider, C., Wong, N., Bredemeyer, A., Hulsmans, M., Nahrendorf, M., et al. (2018). The human heart contains distinct macrophage subsets with divergent origins and functions. Nat. Med. 24, 1234-1245. doi: 10.1038/s41591018-0059- $x$

Baldeviano, G. C., Barin, J. G., Talor, M. V., Srinivasan, S., Bedja, D., Zheng, D., et al. (2010). Interleukin-17A is dispensable for myocarditis but essential for the progression to dilated cardiomyopathy. Circ. Res. 106, 1646-1655. doi: 10.1161/circresaha.109.213157

Bansal, S. S., Ismahil, M. A., Goel, M., Zhou, G., Rokosh, G., Hamid, T., et al. (2019). Dysfunctional and proinflammatory regulatory T-lymphocytes are essential for adverse cardiac remodeling in ischemic cardiomyopathy. Circulation 139, 206-221. doi: 10.1161/circulationaha.118.036065

Berezin, A. E., Berezin, A. A., and Lichtenauer, M. (2021). Myokines and heart failure: challenging role in adverse cardiac remodeling, myopathy, and clinical outcomes. Dis. Markers 2021:6644631.

Berg, A. H., and Scherer, P. E. (2005). Adipose tissue, inflammation, and cardiovascular disease. Circ. Res. 96, 939-949. doi: 10.1111/j.1742-1241.2011. 02717.x

Bock, J. S., and Gottlieb, S. S. (2010). Cardiorenal syndrome: new perspectives. Circulation 121, 2592-2600. doi: 10.1161/circulationaha.109.886473

Bonaventura, A., Montecucco, F., Dallegri, F., Carbone, F., Luscher, T. F., Camici, G. G., et al. (2019). Novel findings in neutrophil biology and their impact on cardiovascular disease. Cardiovasc. Res. 115, 1266-1285. doi: 10.1093/cvr/ cvz084

Braunwald, E. (2008). Biomarkers in heart failure. N. Engl. J. Med. 358, 2148-2159. 
Brower, G. L., and Janicki, J. S. (2005). Pharmacologic inhibition of mast cell degranulation prevents left ventricular remodeling induced by chronic volume overload in rats. J. Card. Fail. 11, 548-556. doi: 10.1016/j.cardfail.2005.05.005

Buckley, L. F., and Abbate, A. (2018). Interleukin-1 blockade in cardiovascular diseases: a clinical update. Eur. Heart J. 39, 2063-2069. doi: 10.1093/eurheartj/ ehy128

Caforio, A. L., Mahon, N. G., Baig, M. K., Tona, F., Murphy, R. T., Elliott, P. M., et al. (2007). Prospective familial assessment in dilated cardiomyopathy: cardiac autoantibodies predict disease development in asymptomatic relatives. Circulation 115, 76-83. doi: 10.1161/circulationaha.106.641472

Cameron, A. R., Morrison, V. L., Levin, D., Mohan, M., Forteath, C., Beall, C., et al. (2016). Anti-inflammatory effects of metformin irrespective of diabetes status. Circ. Res. 119, 652-665. doi: 10.1161/circresaha.116.308445

Carbone, S., Lavie, C. J., and Arena, R. (2017). Obesity and heart failure: focus on the obesity paradox. Mayo Clin. Proc. 92, 266-279. doi: 10.1016/j.mayocp.2016. 11.001

Cavalli, G., Foppoli, M., Cabrini, L., Dinarello, C. A., Tresoldi, M., and Dagna, L. (2017). Interleukin-1 receptor blockade rescues myocarditis-associated end-stage heart failure. Front. Immunol. 8:131. doi: 10.3389/fimmu.2017.00 131

Cavalli, G., Pappalardo, F., Mangieri, A., Dinarello, C. A., Dagna, L., and Tresoldi, M. (2016). Treating life-threatening myocarditis by blocking interleukin-1. Crit. Care Med. 44, e751-e754.

Chan, J. K., Roth, J., Oppenheim, J. J., Tracey, K. J., Vogl, T., Feldmann, M., et al. (2012). Alarmins: awaiting a clinical response. J. Clin. Invest. 122, 2711-2719. doi: $10.1172 /$ jci62423

Chia, S., Nagurney, J. T., Brown, D. F., Raffel, O. C., Bamberg, F., Senatore, F., et al. (2009). Association of leukocyte and neutrophil counts with infarct size, left ventricular function and outcomes after percutaneous coronary intervention for ST-elevation myocardial infarction. Am. J. Cardiol. 103, 333-337. doi: 10.1016/j.amjcard.2008.09.085

Cho, K. I., Kim, B. J., Cha, T. J., Heo, J. H., Kim, H. S., and Lee, J. W. (2015). Impact of duration and dosage of statin treatment and epicardial fat thickness on the recurrence of atrial fibrillation after electrical cardioversion. Heart Vessels 30, 490-497. doi: 10.1007/s00380-014-0505-8

Chung, E. S., Packer, M., Lo, K. H., Fasanmade, A. A., Willerson, J. T., and Anti, T. N. F. T. A. C. H. F. I. (2003). Randomized, double-blind, placebocontrolled, pilot trial of infliximab, a chimeric monoclonal antibody to tumor necrosis factor-alpha, in patients with moderate-to-severe heart failure: results of the anti-TNF Therapy Against Congestive Heart Failure (ATTACH) trial. Circulation 107, 3133-3140. doi: 10.1161/01.cir.0000077913.60364.d2

Coles, B., Fielding, C. A., Rose-John, S., Scheller, J., Jones, S. A., and O’Donnell, V. B. (2007). Classic interleukin-6 receptor signaling and interleukin- 6 transsignaling differentially control angiotensin II-dependent hypertension, cardiac signal transducer and activator of transcription-3 activation, and vascular hypertrophy in vivo. Am. J. Pathol. 171, 315-325. doi: 10.2353/ajpath.2007. 061078

Cordero-Reyes, A. M., Youker, K. A., and Torre-Amione, G. (2013). The role of B-cells in heart failure. Methodist. Debakey Cardiovasc. J. 9, 15-19.

Cordero-Reyes, A. M., Youker, K. A., Trevino, A. R., Celis, R., Hamilton, D. J., Flores-Arredondo, J. H., et al. (2016). Full expression of cardiomyopathy is partly dependent on B-cells: a pathway that involves cytokine activation, immunoglobulin deposition, and activation of apoptosis. J. Am. Heart Assoc. 5:e002484.

Courties, G., Heidt, T., Sebas, M., Iwamoto, Y., Jeon, D., Truelove, J., et al. (2014). In vivo silencing of the transcription factor IRF5 reprograms the macrophage phenotype and improves infarct healing. J. Am. Coll. Cardiol. 63, 1556-1566. doi: 10.1016/j.jacc.2013.11.023

da Silva, E. Z., Jamur, M. C., and Oliver, C. (2014). Mast cell function: a new vision of an old cell. J. Histochem. Cytochem. 62, 698-738. doi: 10.1369/ 0022155414545334

Dalla Libera, L., Sabbadini, R., Renken, C., Ravara, B., Sandri, M., Betto, R., et al. (2001). Apoptosis in the skeletal muscle of rats with heart failure is associated with increased serum levels of TNF-alpha and sphingosine. J. Mol. Cell Cardiol. 33, 1871-1878. doi: 10.1006/jmcc.2001.1453

Delafontaine, P., and Akao, M. (2006). Angiotensin II as candidate of cardiac cachexia. Curr. Opin. Clin. Nutr. Metab. Care 9, 220-224. doi: 10.1097/01.mco. 0000222103.29009 .70
Deswal, A., Petersen, N. J., Feldman, A. M., Young, J. B., White, B. G., and Mann, D. L. (2001). Cytokines and cytokine receptors in advanced heart failure: an analysis of the cytokine database from the vesnarinone trial (VEST). Circulation 103, 2055-2059. doi: 10.1161/01.cir.103.16.2055

Dick, S. A., and Epelman, S. (2016). Chronic heart failure and inflammation: what do we really know? Circ. Res. 119, 159-176. doi: 10.1161/circresaha.116.308030

Dick, S. A., Macklin, J. A., Nejat, S., Momen, A., Clemente-Casares, X., Althagafi, M. G., et al. (2019). Self-renewing resident cardiac macrophages limit adverse remodeling following myocardial infarction. Nat. Immunol. 20, 29-39. doi: 10.1038/s41590-018-0272-2

Ebner, N., Elsner, S., Springer, J., and von Haehling, S. (2014). Molecular mechanisms and treatment targets of muscle wasting and cachexia in heart failure: an overview. Curr. Opin. Support Palliat. Care 8, 15-24. doi: 10.1097/ spc.0000000000000030

Epelman, S., Lavine, K. J., Beaudin, A. E., Sojka, D. K., Carrero, J. A., Calderon, B., et al. (2014). Embryonic and adult-derived resident cardiac macrophages are maintained through distinct mechanisms at steady state and during inflammation. Immunity 40, 91-104. doi: 10.1016/j.immuni.2013.11.019

Eriksson, U., Ricci, R., Hunziker, L., Kurrer, M. O., Oudit, G. Y., Watts, T. H., et al. (2003). Dendritic cell-induced autoimmune heart failure requires cooperation between adaptive and innate immunity. Nat. Med. 9, 1484-1490. doi: 10.1038/ nm960

Everett, B. M., Cornel, J. H., Lainscak, M., Anker, S. D., Abbate, A., Thuren, T., et al. (2019). Anti-inflammatory therapy with canakinumab for the prevention of hospitalization for heart failure. Circulation 139, 1289-1299. doi: 10.1161/ circulationaha.118.038010

Ferraro, B., Leoni, G., Hinkel, R., Ormanns, S., Paulin, N., Ortega-Gomez, A., et al. (2019). Pro-angiogenic macrophage phenotype to promote myocardial repair. J. Am. Coll. Cardiol. 73, 2990-3002. doi: 10.1016/j.jacc.2019.03.503

Francis, G. S., Bartos, J. A., and Adatya, S. (2014). Inotropes. J. Am. Coll. Cardiol. 63, 2069-2078.

Frieler, R. A., and Mortensen, R. M. (2015). Immune cell and other noncardiomyocyte regulation of cardiac hypertrophy and remodeling. Circulation 131, 1019-1030. doi: 10.1161/circulationaha.114.008788

Fukunaga, T., Soejima, H., Irie, A., Sugamura, K., Oe, Y., Tanaka, T., et al. (2007a). Expression of interferon-gamma and interleukin-4 production in CD4+ T cells in patients with chronic heart failure. Heart Vessels 22, 178-183. doi: 10.1007/ s00380-006-0955-8

Fukunaga, T., Soejima, H., Irie, A., Sugamura, K., Oe, Y., Tanaka, T., et al. (2007b). Relation between CD4+ T-cell activation and severity of chronic heart failure secondary to ischemic or idiopathic dilated cardiomyopathy. Am. J. Cardiol. 100, 483-488. doi: 10.1016/j.amjcard.2007.03.052

Getts, D. R., Terry, R. L., Getts, M. T., Deffrasnes, C., Muller, M., van Vreden, C., et al. (2014). Therapeutic inflammatory monocyte modulation using immune-modifying microparticles. Sci. Transl. Med. 6:219ra7. doi: 10.1126/ scitranslmed.3007563

Ghigliotti, G., Barisione, C., Garibaldi, S., Fabbi, P., Brunelli, C., Spallarossa, P., et al. (2014). Adipose tissue immune response: novel triggers and consequences for chronic inflammatory conditions. Inflammation 37, 1337-1353. doi: 10. 1007/s10753-014-9914-1

Gordon, S. (2012). Targeting a monocyte subset to reduce inflammation. Circ. Res. 110, 1546-1548. doi: 10.1161/res.0b013e31825ec26d

Gullestad, L., Aass, H., Fjeld, J. G., Wikeby, L., Andreassen, A. K., Ihlen, H., et al. (2001). Immunomodulating therapy with intravenous immunoglobulin in patients with chronic heart failure. Circulation 103, 220-225. doi: 10.1161/ 01.cir.103.2.220

Guo, C., Ricchiuti, V., Lian, B. Q., Yao, T. M., Coutinho, P., Romero, J. R., et al. (2008). Mineralocorticoid receptor blockade reverses obesity-related changes in expression of adiponectin, peroxisome proliferator-activated receptor-gamma, and proinflammatory adipokines. Circulation 117, 2253-2261. doi: 10.1161/ circulationaha.107.748640

Habibi, J., Aroor, A. R., Sowers, J. R., Jia, G., Hayden, M. R., Garro, M., et al. (2017). Sodium glucose transporter 2 (SGLT2) inhibition with empagliflozin improves cardiac diastolic function in a female rodent model of diabetes. Cardiovasc. Diabetol. 16:9.

Hanberg, J. S., Rao, V. S., Ahmad, T., Chunara, Z., Mahoney, D., Jackson, K., et al. (2018). Inflammation and cardio-renal interactions in heart failure: a potential role for interleukin-6. Eur. J. Heart Fail. 20, 933-934. doi: 10.1002/ejhf.963 
Hara, M., Ono, K., Hwang, M. W., Iwasaki, A., Okada, M., Nakatani, K., et al. (2002). Evidence for a role of mast cells in the evolution to congestive heart failure. J. Exp. Med. 195, 375-381. doi: 10.1084/jem.20002036

Hilgendorf, I., Gerhardt, L. M., Tan, T. C., Winter, C., Holderried, T. A., Chousterman, B. G., et al. (2014). Ly-6Chigh monocytes depend on Nr4al to balance both inflammatory and reparative phases in the infarcted myocardium. Circ. Res. 114, 1611-1622. doi: 10.1161/circresaha.114.303204

Hirata, Y., Kurobe, H., Akaike, M., Chikugo, F., Hori, T., Bando, Y., et al. (2011). Enhanced inflammation in epicardial fat in patients with coronary artery disease. Int. Heart J. 52, 139-142. doi: 10.1536/ihj.52.139

Hirota, H., Yoshida, K., Kishimoto, T., and Taga, T. (1995). Continuous activation of gp130, a signal-transducing receptor component for interleukin 6-related cytokines, causes myocardial hypertrophy in mice. Proc. Natl. Acad. Sci. U.S.A. 92, 4862-4866. doi: 10.1073/pnas.92.11.4862

Horckmans, M., Ring, L., Duchene, J., Santovito, D., Schloss, M. J., Drechsler, M., et al. (2017). Neutrophils orchestrate post-myocardial infarction healing by polarizing macrophages towards a reparative phenotype. Eur. Heart J. 38, $187-197$.

Hou, N., Zhao, D., Liu, Y., Gao, L., Liang, X., Liu, X., et al. (2012). Increased expression of $\mathrm{T}$ cell immunoglobulin- and mucin domain-containing molecule3 on natural killer cells in atherogenesis. Atherosclerosis 222, 67-73. doi: 10. 1016/j.atherosclerosis.2012.02.009

Hulsmans, M., Clauss, S., Xiao, L., Aguirre, A. D., King, K. R., Hanley, A., et al. (2017). Macrophages facilitate electrical conduction in the heart. Cell 169:e20.

Ismahil, M. A., Hamid, T., Bansal, S. S., Patel, B., Kingery, J. R., and Prabhu, S. D. (2014). Remodeling of the mononuclear phagocyte network underlies chronic inflammation and disease progression in heart failure: critical importance of the cardiosplenic axis. Circ. Res. 114, 266-282. doi: 10.1161/circresaha.113.301 720

Jahng, J. W., Song, E., and Sweeney, G. (2016). Crosstalk between the heart and peripheral organs in heart failure. Exp. Mol. Med. 48:e217. doi: 10.1038/emm. 2016.20

Jonasson, L., Backteman, K., and Ernerudh, J. (2005). Loss of natural killer cell activity in patients with coronary artery disease. Atherosclerosis 183, 316-321. doi: 10.1016/j.atherosclerosis.2005.03.011

Jonker, J. T., Lamb, H. J., van der Meer, R. W., Rijzewijk, L. J., Menting, L. J., Diamant, M., et al. (2010). Pioglitazone compared with metformin increases pericardial fat volume in patients with type 2 diabetes mellitus. J. Clin. Endocrinol. Metab. 95, 456-460. doi: 10.1210/jc.2009- 1441

Kacimi, R., Long, C. S., and Karliner, J. S. (1997). Chronic hypoxia modulates the interleukin-1beta-stimulated inducible nitric oxide synthase pathway in cardiac myocytes. Circulation 96, 1937-1943. doi: 10.1161/01.cir.96.6.1937

Kalra, D., Sivasubramanian, N., and Mann, D. L. (2002). Angiotensin II induces tumor necrosis factor biosynthesis in the adult mammalian heart through a protein kinase C-dependent pathway. Circulation 105, 2198-2205. doi: 10. 1161/01.cir.0000015603.84788.47

Kang, S., Tanaka, T., Narazaki, M., and Kishimoto, T. (2019). Targeting interleukin6 signaling in clinic. Immunity 50, 1007-1023. doi: 10.1016/j.immuni.2019.03. 026

Kapadia, S., Lee, J., Torre-Amione, G., Birdsall, H. H., Ma, T. S., and Mann, D. L. (1995). Tumor necrosis factor-alpha gene and protein expression in adult feline myocardium after endotoxin administration. J. Clin. Invest. 96, 1042-1052. doi: $10.1172 /$ jci1 18090

Karason, K., and Jamaly, S. (2020). Heart failure development in obesity: mechanistic pathways. Eur. Heart J. 41:3485. doi: 10.1093/eurheartj/ehaa422

Kaur, K., Sharma, A. K., and Singal, P. K. (2006). Significance of changes in TNF-alpha and IL-10 levels in the progression of heart failure subsequent to myocardial infarction. Am. J. Physiol. Heart Circ. Physiol. 291, H106-H113.

Kaya, Z., Leib, C., and Katus, H. A. (2012). Autoantibodies in heart failure and cardiac dysfunction. Circ. Res. 110, 145-158.

Keliher, E. J., Ye, Y. X., Wojtkiewicz, G. R., Aguirre, A. D., Tricot, B., Senders, M. L., et al. (2017). Polyglucose nanoparticles with renal elimination and macrophage avidity facilitate PET imaging in ischaemic heart disease. Nat. Commun. 8:14064.

Kelly, K. R., Navaneethan, S. D., Solomon, T. P., Haus, J. M., Cook, M., Barkoukis, $\mathrm{H}$., et al. (2014). Lifestyle-induced decrease in fat mass improves adiponectin secretion in obese adults. Med. Sci. Sports Exerc. 46, 920-926. doi: 10.1249/mss. 0000000000000200
Kim, M. K., Tomita, T., Kim, M. J., Sasai, H., Maeda, S., and Tanaka, K. (1985). Aerobic exercise training reduces epicardial fat in obese men. J. Appl. Physiol. 2009, 5-11. doi: 10.1152/japplphysiol.90756.2008

Kubin, T., Poling, J., Kostin, S., Gajawada, P., Hein, S., Rees, W., et al. (2011). Oncostatin $\mathrm{M}$ is a major mediator of cardiomyocyte dedifferentiation and remodeling. Cell Stem Cell 9, 420-432. doi: 10.1016/j.stem.2011.08.013

Kubota, T., McTiernan, C. F., Frye, C. S., Slawson, S. E., Lemster, B. H., Koretsky, A. P., et al. (1997). Dilated cardiomyopathy in transgenic mice with cardiacspecific overexpression of tumor necrosis factor-alpha. Circ. Res. 81, 627-635. doi: 10.1161/01.res.81.4.627

Kuhl, U., and Schultheiss, H. P. (2012). Myocarditis: early biopsy allows for tailored regenerative treatment. Dtsch. Arztebl. Int. 109, 361-368.

Kyne, L., Hausdorff, J. M., Knight, E., Dukas, L., Azhar, G., and Wei, J. Y. (2000). Neutrophilia and congestive heart failure after acute myocardial infarction. Am. Heart J. 139, 94-100. doi: 10.1016/s0002-8703(00)90314-4

Laroumanie, F., Douin-Echinard, V., Pozzo, J., Lairez, O., Tortosa, F., Vinel, C., et al. (2014). CD4+ T cells promote the transition from hypertrophy to heart failure during chronic pressure overload. Circulation 129, 2111-2124. doi: 10.1161/circulationaha.113.007101

Lavie, C. J., Sharma, A., Alpert, M. A., De Schutter, A., Lopez-Jimenez, F., Milani, R. V., et al. (2016). Update on obesity and obesity paradox in heart failure. Prog. Cardiovasc. Dis. 58, 393-400.

Lavine, K. J., Epelman, S., Uchida, K., Weber, K. J., Nichols, C. G., Schilling, J. D., et al. (2014). Distinct macrophage lineages contribute to disparate patterns of cardiac recovery and remodeling in the neonatal and adult heart. Proc. Natl. Acad. Sci. U.S.A. 111, 16029-16034. doi: 10.1073/pnas.1406508111

Lavine, K. J., Pinto, A. R., Epelman, S., Kopecky, B. J., Clemente-Casares, X., Godwin, J., et al. (2018). The macrophage in cardiac homeostasis and disease: JACC macrophage in CVD series (Part 4). J. Am. Coll. Cardiol. 72, 2213-2230.

Lavine, K. J., and Sierra, O. L. (2017). Skeletal muscle inflammation and atrophy in heart failure. Heart Fail. Rev. 22, 179-189. doi: 10.1007/s10741-016-9593-0

Lee, T. M., Chang, N. C., and Lin, S. Z. (2017). Dapagliflozin, a selective SGLT2 Inhibitor, attenuated cardiac fibrosis by regulating the macrophage polarization via STAT3 signaling in infarcted rat hearts. Free Radic. Biol. Med. 104, 298-310. doi: 10.1016/j.freeradbiomed.2017.01.035

Leid, J., Carrelha, J., Boukarabila, H., Epelman, S., Jacobsen, S. E., and Lavine, K. J. (2016). Primitive embryonic macrophages are required for coronary development and maturation. Circ. Res. 118, 1498-1511. doi: 10.1161/ circresaha. 115.308270

Levick, S. P., Melendez, G. C., Plante, E., McLarty, J. L., Brower, G. L., and Janicki, J. S. (2011). Cardiac mast cells: the centrepiece in adverse myocardial remodelling. Cardiovasc. Res. 89, 12-19. doi: 10.1093/cvr/cvq272

Li, K., Guo, D., Zhu, H., Hering-Smith, K. S., Hamm, L. L., Ouyang, J., et al. (2010). Interleukin-6 stimulates epithelial sodium channels in mouse cortical collecting duct cells. Am. J. Physiol. Regul. Integr. Comp. Physiol. 299, R590-R595.

Li, N., Bian, H., Zhang, J., Li, X., Ji, X., and Zhang, Y. (2010). The Th17/Treg imbalance exists in patients with heart failure with normal ejection fraction and heart failure with reduced ejection fraction. Clin. Chim. Acta 411, 1963-1968. doi: 10.1016/j.cca.2010.08.013

Li, Y., Takemura, G., Kosai, K., Takahashi, T., Okada, H., Miyata, S., et al. (2004). Critical roles for the Fas/Fas ligand system in postinfarction ventricular remodeling and heart failure. Circ. Res. 95, 627-636. doi: 10.1161/01.res. 0000141528.54850.bd

Li, Y. P., Schwartz, R. J., Waddell, I. D., Holloway, B. R., and Reid, M. B. (1998). Skeletal muscle myocytes undergo protein loss and reactive oxygen-mediated NF-kappaB activation in response to tumor necrosis factor alpha. FASEB J. 12, 871-880. doi: 10.1096/fasebj.12.10.871

Liao, X., Shen, Y., Zhang, R., Sugi, K., Vasudevan, N. T., Alaiti, M. A., et al. (2018). Distinct roles of resident and nonresident macrophages in nonischemic cardiomyopathy. Proc. Natl. Acad. Sci. U.S.A. 115, E4661-E4669.

Liao, Y. H., Xia, N., Zhou, S. F., Tang, T. T., Yan, X. X., Lv, B. J., et al. (2012). Interleukin-17A contributes to myocardial ischemia/reperfusion injury by regulating cardiomyocyte apoptosis and neutrophil infiltration. J. Am. Coll. Cardiol. 59, 420-429. doi: 10.1016/j.jacc.2011.10.863

Liu, L., Wang, Y., Cao, Z. Y., Wang, M. M., Liu, X. M., Gao, T., et al. (2015). Up-regulated TLR4 in cardiomyocytes exacerbates heart failure after long-term myocardial infarction. J. Cell Mol. Med. 19, 2728-2740. doi: 10.1111/jcmm. 12659 
Liu, S., and Schreur, K. D. (1995). G protein-mediated suppression of L-type Ca2+ current by interleukin-lp in cultured rat ventricular myocytes. Am. J. Cardiol. 268(2 Pt 1), C339-C349.

Liu, Y., Lian, K., Zhang, L., Wang, R., Yi, F., Gao, C., et al. (2014). TXNIP mediates NLRP3 inflammasome activation in cardiac microvascular endothelial cells as a novel mechanism in myocardial ischemia/reperfusion injury. Basic Res. Cardiol. 109:415.

Liu, Y. H., Lu, M., Xie, Z. Z., Hua, F., Xie, L., Gao, J. H., et al. (2014). Hydrogen sulfide prevents heart failure development via inhibition of renin release from mast cells in isoproterenol-treated rats. Antioxid. Redox Signal. 20, 759-769. doi: 10.1089/ars.2012.4888

Lorchner, H., Poling, J., Gajawada, P., Hou, Y., Polyakova, V., Kostin, S., et al. (2015). Myocardial healing requires Reg3beta-dependent accumulation of macrophages in the ischemic heart. Nat. Med. 21, 353-362. doi: 10.1038/nm. 3816

Ma, Z. G., Dai, J., Yuan, Y. P., Bian, Z. Y., Xu, S. C., Jin, Y. G., et al. (2018). T-bet deficiency attenuates cardiac remodelling in rats. Basic Res. Cardiol. 113:19.

Maggioni, A. P., Dahlstrom, U., Filippatos, G., Chioncel, O., Crespo Leiro, M., Drozdz, J., et al. (2013). EURObservational research programme: regional differences and 1-year follow-up results of the Heart Failure Pilot Survey (ESC-HF Pilot). Eur. J. Heart Fail. 15, 808-817. doi: 10.1093/eurjhf/hft050

Mann, D. L. (2002). Inflammatory mediators and the failing heart: past, present, and the foreseeable future. Circ. Res. 91, 988-998. doi: 10.1161/01.res. 0000043825.01705.1b

Mann, D. L. (2015). Innate immunity and the failing heart: the cytokine hypothesis revisited. Circ. Res. 116, 1254-1268. doi: 10.1161/circresaha.116.302317

Mann, D. L., McMurray, J. J., Packer, M., Swedberg, K., Borer, J. S., Colucci, W. S., et al. (2004). Targeted anticytokine therapy in patients with chronic heart failure: results of the randomized etanercept worldwide evaluation (RENEWAL). Circulation 109, 1594-1602. doi: 10.1161/01.cir.0000124490. 27666.b2

Mann, D. L., Topkara, V. K., Evans, S., and Barger, P. M. (2010). Innate immunity in the adult mammalian heart: for whom the cell tolls. Trans. Am. Clin. Climatol. Assoc. 121, 34-50.

Markousis-Mavrogenis, G., Tromp, J., Ouwerkerk, W., Devalaraja, M., Anker, S. D., Cleland, J. G., et al. (2019). The clinical significance of interleukin-6 in heart failure: results from the BIOSTAT-CHF study. Eur. J. Heart Fail. 21, 965-973. doi: 10.1002/ejhf.1482

Marriott, J. B., Goldman, J. H., Keeling, P. J., Baig, M. K., Dalgleish, A. G., and McKenna, W. J. (1996). Abnormal cytokine profiles in patients with idiopathic dilated cardiomyopathy and their asymptomatic relatives. Heart 75, 287-290. doi: $10.1136 /$ hrt.75.3.287

Martini, E., Kunderfranco, P., Peano, C., Carullo, P., Cremonesi, M., and Schorn, T. (2019). Single cell sequencing of mouse heart immune infiltrate in pressure overload-driven heart failure reveals extent of immune activation. Circulation 140, 2089-2107. doi: 10.1161/circulationaha.119.041694

Meng, X., Yang, J., Dong, M., Zhang, K., Tu, E., Gao, Q., et al. (2016). Regulatory T cells in cardiovascular diseases. Nat. Rev. Cardiol. 13, 167-179.

Mildner, A., and Jung, S. (2014). Development and function of dendritic cell subsets. Immunity 40, 642-656. doi: 10.1016/j.immuni.2014.04.016

Monden, Y., Kubota, T., Inoue, T., Tsutsumi, T., Kawano, S., Ide, T., et al. (2007). Tumor necrosis factor-alpha is toxic via receptor 1 and protective via receptor 2 in a murine model of myocardial infarction. Am. J. Physiol. Heart Circ. Physiol. 293, H743-H753.

Mosterd, A., and Hoes, A. W. (2007). Clinical epidemiology of heart failure. Heart 93, 1137-1146. doi: 10.1136/hrt.2003.025270

Mukai, K., Tsai, M., Saito, H., and Galli, S. J. (2018). Mast cells as sources of cytokines, chemokines, and growth factors. Immunol. Rev. 282, 121-150. doi: $10.1111 /$ imr.12634

Murphy, S. P., Kakkar, R., McCarthy, C. P., and Januzzi, J. L. Jr. (2020). Inflammation in heart failure: JACC state-of-the-art review. J. Am. Coll. Cardiol. $75,1324-1340$.

Nevers, T., Salvador, A. M., Grodecki-Pena, A., Knapp, A., Velazquez, F., Aronovitz, M., et al. (2015). Left ventricular T-cell recruitment contributes to the pathogenesis of heart failure. Circ. Heart Fail. 8, 776-787. doi: 10.1161/ circheartfailure.115.002225

Noutsias, M., Pauschinger, M., Schultheiss, H., and Kh, U. (2002). Phenotypic characterization of infiltrates in dilated cardiomyopathy - diagnostic significance of T-lymphocytes and macrophages in inflammatory cardiomyopathy. Med. Sci. Monit. 8, CR478-CR487.

Oikonomou, E. K., and Antoniades, C. (2019). The role of adipose tissue in cardiovascular health and disease. Nat. Rev. Cardiol. 16, 83-99.

Okamoto, N., Noma, T., Ishihara, Y., Miyauchi, Y., Takabatake, W., Oomizu, S., et al. (2014). Prognostic value of circulating regulatory $\mathrm{T}$ cells for worsening heart failure in heart failure patients with reduced ejection fraction. Int. Heart J. 55, 271-277. doi: 10.1536/ihj.13-343

Okuyama, M., Yamaguchi, S., Nozaki, N., Yamaoka, M., Shirakabe, M., and Tomoike, H. (1997). Serum levels of soluble form of Fas molecule in patients with congestive heart failure. Am. J. Cardiol. 79, 1698-1701. doi: 10.1016/ s0002-9149(97)00228-2

Olivier, A., Pitt, B., Girerd, N., Lamiral, Z., Machu, J. L., McMurray, J. J. V., et al. (2017). Effect of eplerenone in patients with heart failure and reduced ejection fraction: potential effect modification by abdominal obesity. Insight from the EMPHASIS-HF trial. Eur. J. Heart Fail. 19, 1186-1197. doi: 10.1002/ejhf.792

Ong, S., Rose, N. R., and Cihakova, D. (2017). Natural killer cells in inflammatory heart disease. Clin. Immunol. 175, 26-33. doi: 10.1016/j.clim.2016.11.010

Ouyang, W., Rutz, S., Crellin, N. K., Valdez, P. A., and Hymowitz, S. G. (2011). Regulation and functions of the IL-10 family of cytokines in inflammation and disease. Annu. Rev. Immunol. 29, 71-109. doi: 10.1146/annurev-immunol031210-101312

Packer, M. (2018). Epicardial adipose tissue may mediate deleterious effects of obesity and inflammation on the myocardium. J. Am. Coll. Cardiol. 71, 23602372. doi: 10.1016/j.jacc.2018.03.509

Patel, B., Bansal, S. S., Ismahil, M. A., Hamid, T., Rokosh, G., Mack, M., et al. (2018). CCR2(+) monocyte-derived infiltrating macrophages are required for adverse cardiac remodeling during pressure overload. JACC Basic Transl. Sci. 3, 230-244. doi: 10.1016/j.jacbts.2017.12.006

Patel, V. B., Shah, S., Verma, S., and Oudit, G. Y. (2017). Epicardial adipose tissue as a metabolic transducer: role in heart failure and coronary artery disease. Heart Fail. Rev. 22, 889-902. doi: 10.1007/s10741-017-9644-1

Paulus, W. J., and Tschope, C. (2013). A novel paradigm for heart failure with preserved ejection fraction: comorbidities drive myocardial dysfunction and remodeling through coronary microvascular endothelial inflammation. J. Am. Coll. Cardiol. 62, 263-271.

Peschel, T., Schönauer, M., Thiele, H., Anker, S., Schuler, G., and Niebauer, J. (2003). Invasive assessment of bacterial endotoxin and inflammatory cytokines in patients with acute heart failure. Eur. J. Heart Fail. 5, 609-614. doi: 10.1016/ s1388-9842(03)00104-1

Pinto, A. R., Ilinykh, A., Ivey, M. J., Kuwabara, J. T., D’Antoni, M. L., Debuque, R., et al. (2016). Revisiting cardiac cellular composition. Circ. Res. 118, 400-409. doi: $10.1161 /$ circresaha.115.307778

Pistulli, R., Hammer, N., Rohm, I., Kretzschmar, D., Jung, C., Figulla, H. R., et al. (2016). Decrease of circulating myeloid dendritic cells in patients with chronic heart failure. Acta Cardiol. 71, 165-172. doi: 10.1080/ac.71.2.3141846

Pistulli, R., Konig, S., Drobnik, S., Kretzschmar, D., Rohm, I., Lichtenauer, M., et al. (2013). Decrease in dendritic cells in endomyocardial biopsies of human dilated cardiomyopathy. Eur. J. Heart Fail. 15, 974-985. doi: 10.1093/eurjhf/hft 054

Plenz, G., Song, Z. F., Tjan, T. D., Koenig, C., Baba, H. A., Erren, M., et al. (2001). Activation of the cardiac interleukin-6 system in advanced heart failure. Eur. J. Heart Fail. 3, 415-421. doi: 10.1016/s1388-9842(01)00137-4

Ponikowski, P., Voors, A. A., Anker, S. D., Bueno, H., Cleland, J. G., Coats, A. J., et al. (2016). ESC Guidelines for the diagnosis and treatment of acute and chronic heart failure: the Task Force for the diagnosis and treatment of acute and chronic heart failure of the European Society of Cardiology (ESC). Developed with the special contribution of the Heart Failure Association (HFA) of the ESC. Eur. J. Heart Fail. 18, 891-975.

Ramos, G. C., van den Berg, A., Nunes-Silva, V., Weirather, J., Peters, L., Burkard, M., et al. (2017). Myocardial aging as a T-cell-mediated phenomenon. Proc. Natl. Acad. Sci. U.S.A. 114, E2420-E2429.

Rauchhaus, M., Doehner, W., Francis, D. P., Davos, C., Kemp, M., Liebenthal, C., et al. (2000). Plasma cytokine parameters and mortality in patients with chronic heart failure. Circulation 102, 3060-3067. doi: 10.1161/01.cir.102.25.3060

Ruiz-Ortega, M., Ruperez, M., Lorenzo, O., Esteban, V., Blanco, J., Mezzano, S., et al. (2002). Angiotensin II regulates the synthesis of proinflammatory cytokines and chemokines in the kidney. Kidney Int. Suppl. 82, S12-S22. 
Sager, H. B., Heidt, T., Hulsmans, M., Dutta, P., Courties, G., Sebas, M., et al. (2015). Targeting interleukin-1beta reduces leukocyte production after acute myocardial infarction. Circulation 132, 1880-1890. doi: 10.1161/circulationaha. 115.016160

Sager, H. B., Hulsmans, M., Lavine, K. J., Moreira, M. B., Heidt, T., Courties, G., et al. (2016). Proliferation and recruitment contribute to myocardial macrophage expansion in chronic heart failure. Circ. Res. 119, 853-864. doi: 10.1161/circresaha.116.309001

Sandanger, O., Ranheim, T., Vinge, L. E., Bliksoen, M., Alfsnes, K., Finsen, A. V., et al. (2013). The NLRP3 inflammasome is up-regulated in cardiac fibroblasts and mediates myocardial ischaemia-reperfusion injury. Cardiovasc. Res. 99, 164-174. doi: 10.1093/cvr/cvt091

Sandek, A., Bjarnason, I., Volk, H. D., Crane, R., Meddings, J. B., Niebauer, J., et al. (2012). Studies on bacterial endotoxin and intestinal absorption function in patients with chronic heart failure. Int. J. Cardiol. 157, 80-85. doi: 10.1016/j. ijcard.2010.12.016

Seta, Y., Shan, K., Bozkurt, B., Oral, H., and Mann, D. L. (1996). Basic mechanisms in heart failure: the cytokine hypothesis. J. Card. Fail. 2, 243-249. doi: 10.1016/ s1071-9164(96)80047-9

Sharma, K., Patel, A. K., Shah, K. H., and Konat, A. (2017). Is neutrophil-tolymphocyte ratio a predictor of coronary artery disease in Western Indians? Int. J. Inflam. 2017;4136126.

Sukhanov, S., Semprun-Prieto, L., Yoshida, T., Michael Tabony, A., Higashi, Y., Galvez, S., et al. (2011). Angiotensin II, oxidative stress and skeletal muscle wasting. Am. J. Med. Sci. 342, 143-147. doi: 10.1097/maj.0b013e318222e620

Swirski, F. K., Nahrendorf, M., Etzrodt, M., Wildgruber, M., Cortez-Retamozo, V., Panizzi, P., et al. (2009). Identification of splenic reservoir monocytes and their deployment to inflammatory sites. Science 325, 612-616. doi: 10.1126/science. 1175202

Tang, H., Zhong, Y., Zhu, Y., Zhao, F., Cui, X., and Wang, Z. (2010). Low responder $\mathrm{T}$ cell susceptibility to the suppressive function of regulatory $\mathrm{T}$ cells in patients with dilated cardiomyopathy. Heart 96, 765-771. doi: 10.1136/hrt.2009.184945

Tang, T. T., Ding, Y. J., Liao, Y. H., Yu, X., Xiao, H., Xie, J. J., et al. (2010). Defective circulating CD4CD25+Foxp3+CD127(low) regulatory T-cells in patients with chronic heart failure. Cell Physiol. Biochem. 25, 451-458. doi: 10.1159/ 000303050

Tang, T. T., Zhu, Z. F., Wang, J., Zhang, W. C., Tu, X., Xiao, H., et al. (2011). Impaired thymic export and apoptosis contribute to regulatory $\mathrm{T}$-cell defects in patients with chronic heart failure. PLoS One 6:e24272. doi: 10.1371/journal. pone. 0024272

Tang, Z., McGowan, B. S., Huber, S. A., McTiernan, C. F., Addya, S., Surrey, S., et al. (2004). Gene expression profiling during the transition to failure in TNFalpha over-expressing mice demonstrates the development of autoimmune myocarditis. J. Mol. Cell Cardiol. 36, 515-530. doi: 10.1016/j.yjmcc.2004.01.008

Testa, M., Yeh, M., Lee, P., Fanelli, R., Loperfido, F., Berman, J. W., et al. (1996). Circulating levels of cytokines and their endogenous modulators in patients with mild to severe congestive heart failure due to coronary artery disease or hypertension. J. Am. Coll. Cardiol. 28, 964-971. doi: 10.1016/s0735-1097(96) 00268-9

Torre-Amione, G., Kapadia, S., Benedict, C., Oral, H., Young, J. B., and Mann, D. L. (1996). Proinflammatory cytokine levels in patients with depressed left ventricular ejection fraction: a report from the studies of left ventricular dysfunction (SOLVD). J. Am. Coll. Cardiol. 27, 1201-1206. doi: 10.1016/07351097(95)00589-7

Tosello-Trampont, A., Surette, F. A., Ewald, S. E., and Hahn, Y. S. (2017). Immunoregulatory role of NK cells in tissue inflammation and regeneration. Front. Immunol. 8:301. doi: 10.3389/fimmu.2017.00301

Tromp, J., Khan, M. A., Klip, I. T., Meyer, S., de Boer, R. A., Jaarsma, T., et al. (2017). Biomarker profiles in heart failure patients with preserved and reduced ejection fraction. J. Am. Heart Assoc. 6:e003989.

Tromp, J., Tay, W. T., Ouwerkerk, W., Teng, T. K., Yap, J., MacDonald, M. R., et al. (2018a). Multimorbidity in patients with heart failure from 11 Asian regions: a prospective cohort study using the ASIAN-HF registry. PLoS Med. 15:e1002541. doi: 10.1371/journal.pmed.1002541

Tromp, J., Westenbrink, B. D., Ouwerkerk, W., van Veldhuisen, D. J., Samani, N. J., Ponikowski, P., et al. (2018b). Identifying pathophysiological mechanisms in heart failure with reduced versus preserved ejection fraction. J. Am. Coll. Cardiol. 72, 1081-1090.
Tschope, C., Van Linthout, S., Spillmann, F., Posch, M. G., Reinke, P., Volk, H. D., et al. (2019). Targeting CD20+ B-lymphocytes in inflammatory dilated cardiomyopathy with rituximab improves clinical course: a case series. Eur. Heart J. Case Rep. 3:ytz131.

Ukimura, A., Terasaki, F., Fujioka, S., Deguchi, H., Kitaura, Y., Isomura, T., et al. (2003). Quantitative analysis of cytokine mRNA expression in hearts from patients with nonischemic dilated cardiomyopathy (DCM). J. Card Surg. 18(Suppl. 2), S101-S108.

Uthamalingam, S., Patvardhan, E. A., Subramanian, S., Ahmed, W., Martin, W., Daley, M., et al. (2011). Utility of the neutrophil to lymphocyte ratio in predicting long-term outcomes in acute decompensated heart failure. Am. J. Cardiol. 107, 433-438. doi: 10.1016/j.amjcard.2010.09.039

van der Laan, A. M., Ter Horst, E. N., Delewi, R., Begieneman, M. P., Krijnen, P. A., Hirsch, A., et al. (2014). Monocyte subset accumulation in the human heart following acute myocardial infarction and the role of the spleen as monocyte reservoir. Eur. Heart J. 35, 376-385. doi: 10.1093/eurheartj/eht331

van Hout, G. P., van Solinge, W. W., Gijsberts, C. M., Teuben, M. P., Leliefeld, P. H., Heeres, M., et al. (2015). Elevated mean neutrophil volume represents altered neutrophil composition and reflects damage after myocardial infarction. Basic Res. Cardiol. 110:58.

Van Tassell, B. W., Arena, R. A., Toldo, S., Mezzaroma, E., Azam, T., Seropian, I. M., et al. (2012). Enhanced interleukin-1 activity contributes to exercise intolerance in patients with systolic heart failure. PLoS One 7:e33438. doi: 10.1371/journal. pone. 0033438

Van Tassell, B. W., Seropian, I. M., Toldo, S., Mezzaroma, E., and Abbate, A. (2013a). Interleukin-1 $\beta$ induces a reversible cardiomyopathy in the mouse. Inflamm. Res. 62, 637-640. doi: 10.1007/s00011-013-0625-0

Van Tassell, B. W., Toldo, S., Mezzaroma, E., and Abbate, A. (2013b). Targeting interleukin-1 in heart disease. Circulation 128, 1910-1923. doi: 10.1161/ circulationaha.113.003199

Vazquez, M. I., Catalan-Dibene, J., and Zlotnik, A. (2015). B cells responses and cytokine production are regulated by their immune microenvironment. Cytokine 74, 318-326. doi: 10.1016/j.cyto.2015.02.007

Verbrugge, F. H., Dupont, M., Steels, P., Grieten, L., Malbrain, M., Tang, W. H., et al. (2013). Abdominal contributions to cardiorenal dysfunction in congestive heart failure. J. Am. Coll. Cardiol. 62, 485-495. doi: 10.1016/j.jacc.2013.04.070

Vivier, E., Raulet, D. H., Moretta, A., Caligiuri, M. A., Zitvogel, L., Lanier, L. L., et al. (2011). Innate or adaptive immunity? The example of natural killer cells. Science 331, 44-49.

von Haehling, S., Steinbeck, L., Doehner, W., Springer, J., and Anker, S. D. (2013). Muscle wasting in heart failure: an overview. Int. J. Biochem. Cell Biol. 45, 2257-2265.

Vredevoe, D. L., Widawski, M., Fonarow, G. C., Hamilton, M., Martinez-Maza, O., and Gage, J. R. (2004). Interleukin-6 (IL-6) expression and natural killer (NK) cell dysfunction and anergy in heart failure. Am. J. Cardiol. 93, 1007-1011. doi: 10.1016/j.amjcard.2003.12.054

Wang, H., Hou, L., Kwak, D., Fassett, J., Xu, X., Chen, A., et al. (2016). Increasing regulatory $\mathrm{T}$ cells with interleukin- 2 and interleukin- 2 antibody complexes attenuates lung inflammation and heart failure progression. Hypertension 68, 114-122. doi: 10.1161/hypertensionaha.116.07084

Wang, J., Seo, M. J., Deci, M. B., Weil, B. R., Canty, J. M., and Nguyen, J. (2018). Effect of CCR2 inhibitor-loaded lipid micelles on inflammatory cell migration and cardiac function after myocardial infarction. Int. J. Nanomedicine 13, 6441-6451. doi: 10.2147/ijn.s178650

Weinberg, E. O., Shimpo, M., Hurwitz, S., Tominaga, S., Rouleau, J. L., and Lee, R. T. (2003). Identification of serum soluble ST2 receptor as a novel heart failure biomarker. Circulation 107, 721-726. doi: 10.1161/01.cir.0000047274.667 49.fe

Wernstedt Asterholm, I., Tao, C., Morley, T. S., Wang, Q. A., Delgado-Lopez, F., Wang, Z. V., et al. (2014). Adipocyte inflammation is essential for healthy adipose tissue expansion and remodeling. Cell Metab. 20, 103-118. doi: 10. 1016/j.cmet.2014.05.005

West, N. R., Hegazy, A. N., Owens, B. M. J., Bullers, S. J., Linggi, B., Buonocore, S., et al. (2017). Oncostatin $M$ drives intestinal inflammation and predicts response to tumor necrosis factor-neutralizing therapy in patients with inflammatory bowel disease. Nat. Med. 23, 579-589. doi: 10.1038/nm.4307

Wollenweber, T., Roentgen, P., Schafer, A., Schatka, I., Zwadlo, C., Brunkhorst, T., et al. (2014). Characterizing the inflammatory tissue response to acute 
myocardial infarction by clinical multimodality noninvasive imaging. Circ. Cardiovasc. Imaging 7, 811-818. doi: 10.1161/circimaging.114.001689

Xia, Y., Lee, K., Li, N., Corbett, D., Mendoza, L., and Frangogiannis, N. G. (2009). Characterization of the inflammatory and fibrotic response in a mouse model of cardiac pressure overload. Histochem. Cell Biol. 131, 471-481. doi: 10.1007/ s00418-008-0541-5

Yamada, Y., Takeuchi, S., Yoneda, M., Ito, S., Sano, Y., Nagasawa, K., et al. (2017). Atorvastatin reduces cardiac and adipose tissue inflammation in rats with metabolic syndrome. Int. J. Cardiol. 240, 332-338. doi: 10.1016/j.ijcard.2017. 04.103

Yan, X., Anzai, A., Katsumata, Y., Matsuhashi, T., Ito, K., Endo, J., et al. (2013). Temporal dynamics of cardiac immune cell accumulation following acute myocardial infarction. J. Mol. Cell Cardiol. 62, 24-35. doi: 10.1016/j.yjmcc. 2013.04.023

Yancy, C. W., Jessup, M., Bozkurt, B., Butler, J., Casey, D. E. Jr., Colvin, M. M., et al. (2017). ACC/AHA/HFSA focused update of the 2013 ACCF/AHA guideline for the management of heart failure: a report of the american college of cardiology/american heart association task force on clinical practice guidelines and the Heart Failure Society of America. Circulation 136, e137-e161.

Yndestad, A. (2003). Enhanced expression of inflammatory cytokines and activation markers in T-cells from patients with chronic heart failure. Cardiovasc. Res. 60, 141-146. doi: 10.1016/s0008-6363(03)00362-6

Zhang, W., Chancey, A. L., Tzeng, H. P., Zhou, Z., Lavine, K. J., Gao, F., et al. (2011). The development of myocardial fibrosis in transgenic mice with targeted overexpression of tumor necrosis factor requires mast cell-fibroblast interactions. Circulation 124, 2106-2116. doi: 10.1161/circulationaha.111. 052399

Zhang, W., Wang, W., Yu, H., Zhang, Y., Dai, Y., Ning, C., et al. (2012). Interleukin 6 underlies angiotensin II-induced hypertension and chronic renal damage. Hypertension 59, 136-144. doi: 10.1161/hypertensionaha.111.173328

Zimmet, J. M., and Hare, J. M. (2006). Nitroso-redox interactions in the cardiovascular system. Circulation 114, 1531-1544. doi: 10.1161/ circulationaha.105.605519

Zouggari, Y., Ait-Oufella, H., Bonnin, P., Simon, T., Sage, A. P., Guerin, C., et al. (2013). B lymphocytes trigger monocyte mobilization and impair heart function after acute myocardial infarction. Nat. Med. 19, 1273-1280. doi: 10.1038/nm. 3284

Conflict of Interest: The authors declare that the research was conducted in the absence of any commercial or financial relationships that could be construed as a potential conflict of interest.

Copyright (c) $2021 \mathrm{Li}$, Chen and Wang. This is an open-access article distributed under the terms of the Creative Commons Attribution License (CC BY). The use, distribution or reproduction in other forums is permitted, provided the original author(s) and the copyright owner(s) are credited and that the original publication in this journal is cited, in accordance with accepted academic practice. No use, distribution or reproduction is permitted which does not comply with these terms. 